\title{
Summary of eleven long-term field trials with 'Longlife' phosphatic fertiliser
}

\author{
S.F. LEDGARD', B.S. THORROLD, A.G. SINCLAIR. S.S.S. RAJAN' and D.C. EDMEADES' \\ 1 AgResearch Ruakura Agricultural Centre. Private Bag, Hamilton \\ 2 AgResearch Whatowhata Agricultural Centre, Private Bag, Hamilton \\ ${ }_{3}$ AgResearch Invermay Agricultural Centre, Private Bag. Hamilton
}

\begin{abstract}
Longlife' phosphatic fertiliser is manufactured in New Zealand by mixing reactive phosphate rock (RPR) with single superphosphate (SSP) when the SSP is at an ex-den stage. Commercially produced Longlife (70:30 SSP:RPR) was evaluated in 6 field mowing trials in the North Island over 3 or 4 years. Also, a 50:50 (SSP:RPR) Longlife-type product was examined in 5 field trials throughout New Zealand over 5 or 6 years. Longlife was compared against SSP and/or triple superphosphate (TSP) in all trials, and RPR treatments were included in 7 trials. In all trials with commercially produced Longlife, the pasture response to Longlife tended to be less than that to SSP or TSP in the first 2 years and was significantly different $(\mathrm{P}<0.01$ in year 1 , $P<0.07$ in year 2) for the average of all trials. Differences generally decreased over time. In the trials with RPR, Longlife tended to be intermediate between RPR and SSP. Thus, Longlife performed as expected from a simple non-interactive mixture of its components. This indicates that it is inappropriate for use where field conditions are unsuitable for RPR use (i.e. soil $\mathrm{pH}>6.0$ and/or rainfall $<800$ $\mathrm{mm} /$ year).
\end{abstract}

Keywords field trials, Longlife, phosphate, reactive phosphate rock, superphosphate

\section{Introduction}

'Longlife' has been produced by New Zealand fertiliser manufacturers since 1985 by mixing reactive phosphate rock (RPR) with single superphosphate (SSP) when the SSP was at an ex-den stage. The main commercial form of Longlife has been a 70:30 SSP:RPR mixture. During 1989 and 1990. a survey by MRL Research Group of farms indicated that Longlife constituted 20 and $26 \%$, respectively, of the totalamountofphosphatic fertiliser applied ondairy and sheep/beef farms throughout New Zealand.

The only published field trials with Longlife (Mackay \& Wewela 1990) were from 2 sites on a yellow-brown earth soil and involved comparison of Longlife (one rate) with 3 rates of RPR and SSP (all replicated twice) in the southern Ruahiies. Both sites responded to P but no significant difference was detected in total pasture production ova 2 years between any $\mathrm{P}$ fertilisers. However, at one site, legume production was stimulated more during the first 6 months from Longlife and SSP than from RPR.

The detection of real differences between phosphatic fertilisers which do not vary greatly in their $\mathrm{P}$ availability is very difficult in the field. Johnstone and Sinclair (1991) showed that to detect significant differences between products such as Longlife and SSP it is necessary to have a highly $\mathrm{P}$ responsive site and a high degree of replication; eg. 2 fertilisers with a $10 \%$ difference in $\mathrm{P}$ availability compared on a $100 \%$ responsive site may require about 40 replicates to ensure a $90 \%$ probability of detecting the difference between them. In practice. individual field experiments rarely meet these criteria. Clearly, conclusionsregarding the suitability of different phosphatic fertilisers are best made only after considering the collective results from a number of trials.

This paper summarises the results from 11 field trials which evaluated commercial Longlife or Longlife-type phosphatic fertiliser over 3 to 6 years.

\section{Methods}

Sites and experlmental procedure

Details of the 11 trial sites aregivein Table 1. Further details of sites 7-1 I were given by Smith $\boldsymbol{e t}$ al. (1991). In all trials, areas were selected and fenced to exclude animals for the trial duration. Pasture production was measured by mowing at 15 - 60 day intervals depending on pasture growth rate. All clippings (or $50 \%$ in trials 5 and 6 , and $70 \%$ in trials 1 and 2) were evenly reapplied onto plots. Trials 1 to 6 had uniformity cuts taken prior to the first application of fertiliser. Basal dressings of sulphur, potassium and trace elements (some sites only) were applied regularly.

\section{Longlife fertiliser}

The commercial Longlife fertilisers used in trials 1 - 6 were manufactured from $70 \%$ SSP (made mainly from Nauru and Xmas Island PRs) and 30\% RPR (North 
Table 1 Summary of site and soil chancteristics of Longlife field trials

\begin{tabular}{|c|c|c|c|c|c|c|}
\hline & Location & Soil group & $\begin{array}{l}\text { Raintall } \\
\text { (mm/year) }\end{array}$ & $\mathrm{pH}$ & $\begin{array}{c}\text { Olsen } \\
\mathbf{P}\end{array}$ & $\begin{array}{l}\text { Trial } \\
\text { duration } \\
\text { (vears) }\end{array}$ \\
\hline \multicolumn{7}{|c|}{ Commerclal Longllfe } \\
\hline 4. & Kaharoa & "Yellow brown pumice & 1600 & 5.6 & 23 & 3 \\
\hline 2. & Taupo & Yellow brown pumice & 1200 & 5.8 & 32 & 3 \\
\hline 3. & Hamilton & Yellow brown loam & 1250 & 5.7 & 17 & 3 \\
\hline 4. & Hamilton & Yellow brown loam & 1250 & 5.6 & 14 & 4 \\
\hline 5. & Te Kuit & Yellow brown loam & 1450 & 5.6 & 6 & 4 \\
\hline 6. & Te Kuiti & Yellow brown loam & 1450 & 5.6 & 11 & 4 \\
\hline \multicolumn{7}{|c|}{ 50:50 Longlito-type fertiliser } \\
\hline 7. & Te Kuit & Yellow brown loam & 1450 & 5.6 & 10 & 6 \\
\hline 6. & Meremere & Yellow brown loam & 1200 & 5.9 & 16 & 5 \\
\hline Q. & Winchmore & Yellow Qrey earth & $770^{\prime}$ & 5.6 & 7 & 6 \\
\hline 10 & Woodlands & Yellow brown earth & 1040 & 5.9 & 13 & 6 \\
\hline 11 & Gore & Yellow grey earth & 890 & 5.6 & 14 & 6 \\
\hline
\end{tabular}

The site also received $500 \mathrm{~mm}$ In Irrigation water

Carolina, unground) added ex-den. The 50:50 Longlifetypefertiliserusedintrials 7-11 was prepared from $50 \%$ SSP (made from a 50:50 mix of Nauru and Xmas Island PRs) and 50\% RPR (North Carolina) by the former NZFMRA in a small-scale fertiliser plant with RPR being added to SSPex-den (A Braithwaite pers. comm.). Chemical analyses of these products are given in Table 2 .

Table $\mathbf{2}$ Chemical analyses of Longlife and other $\boldsymbol{P}$ ferilisers used in the field aids

\begin{tabular}{llll}
\hline Trial No. & Total & Citric-soluble $P$ & Water-soluble $P$ \\
& $\mathbf{P ( \% )}$ & (as \% Of total $\mathrm{P})$ & (as \% Of total $\mathbf{P})$ \\
\hline
\end{tabular}

\begin{tabular}{|c|c|c|c|c|}
\hline \multicolumn{5}{|c|}{ Commerclal Longllfe } \\
\hline \multicolumn{2}{|c|}{1,2} & 10.4 & 67 & 46 \\
\hline \multicolumn{2}{|l|}{3} & 10.8 & 62 & 44 \\
\hline \multicolumn{2}{|l|}{4} & 10.3 & 65 & 50 \\
\hline \multirow{2}{*}{\multicolumn{2}{|c|}{$\begin{array}{l}5.6 \\
\text { mean }\end{array}$}} & 10.3 & 63 & 41 \\
\hline & & 10.4 & 64 & 46 \\
\hline \multicolumn{5}{|c|}{ 50:50 Longllifo-type fortiliser } \\
\hline $7-$ & 11 & 11.4 & 54 & \\
\hline \multicolumn{5}{|l|}{ ssp } \\
\hline 3 & & 9.3 & 97 & 96 \\
\hline 4 & & 9.1 & 66 & 81 \\
\hline 5,6 & & 9.5 & 66 & 77 \\
\hline $7-$ & 11 & 9.4 & 66 & 77 \\
\hline \multicolumn{5}{|l|}{ TSP } \\
\hline 1,2 & & 18.4 & 66 & 71 \\
\hline $7-11$ & & 20.6 & 94 & 91 \\
\hline North & Carollna & RPR & & \\
\hline 5,6 & & i2.6 & 30 & \\
\hline 7 . & 11 & 12.6 & 32 & \\
\hline
\end{tabular}

Design of trials

Trials 1 and 2. Treatments (on a total $\mathrm{P}$ basis) were 0,10 , $20,35,50$ and $80 \mathrm{kgP} / \mathrm{ha} / \mathrm{year}$ of triple superphosphate (TSP) and 20.35 and $50 \mathrm{kgP} / \mathrm{ha} / \mathrm{year}$ of commercial Longlife. There were 5 replicates in arandomised block design.

Trial 3. Treatments (on a total $\mathrm{P}$ basis) were $\mathbf{0 , 2 2 , 4 4}$ and $66 \mathrm{kgP} / \mathrm{ha} /$ year of SSP and of commercial Longlife. There were 4 replicates in a randomised block design.

Trial 4. Treatments (on a total $\mathrm{P}$ basis) were $\mathbf{0 , 2 2 . 5}$, 30 and $60 \mathrm{kgP} / \mathrm{ha} /$ year of SSP and of commercial Longlife. There were 4 replicates in a randomised block design.

Trials 5 and 6 . Treatments were $0,15,30$ and $45 \mathrm{kgP} /$ ha/year of Longlife (based on $9.6 \%$ 'available' P) and SSP (based on $2 \%$ citric-soluble P), and 15 and $30 \mathrm{kgP} /$ ha/year of North Carolina RPR (on a totalPbasis). There were 4 replicates in a randomised block design.

Trials 7 - 11. Treatments (on a total $\mathrm{P}$ basis) included annual applications of $\mathbf{0}, 0.5,0.75,1.0$ and $2.0 \mathrm{x}$ maintenance (M) P rate of TSP (see Smith et al. 1991 for details). These 5 trials also had SSP (from 50\% Nauru and 50\% Xmas Island PRs), a 50:50 Longlife-type fertiliser (made from 50\% Nauru/Xmas SSP and 50\% North Carolina RPR), and North Carolina RPR, all applied at $0.75 \mathrm{M}$. All treatments were replicated thrice.

Calculations and data analysis

Analysis of variance was done on data from all trials and the LSD (5\%) was estimated. Thesubstitutionvalue ( $\Psi$ ) was calculated (Johnstone \& Sinclair 1991) for all trials. This is the ratio of total $\mathrm{P}$ in SSP or TSP to total $\mathrm{P}$ in 
Longlife required to give the same pasture yield over a specified time interval (eg., $1 \mathrm{~kg} \mathbf{P}_{\text {Lomglifo }}=\boldsymbol{\Psi} \mathrm{kg} \mathbf{P}_{\text {ssP }}$ ).

\section{Results}

\section{Commercial Longlife trials}

In all years and for all trials there was a significant response to added $\mathrm{P}$, which averaged $7-10 \%$ in year 1 and $9-24 \%$ in year 3 for SSP or TSP (Table 3). In all trials the response to $\mathrm{P}$ generally increased over all rates applied and therefore data is presented as the mean of the 3 rates. for the sake of brevity (Table 3 ).

In the first year, over all trials Longlife was lower yielding $(\mathrm{P}<0.01)$ than SSP or TSP, with an average relative response of $76 \%$. although differences were not statistically significant in any one trial. This continued into year 2. although the relative difference between responses to Longlife and SSP or TSP had decreased $(\mathrm{P}<0.07$; relative response of $81 \%$ ). In year 2 . Longlife was lower yielding $(P<0.05)$ than SSP in trial 6 with the effect reaching significance due to therelatively large $P$ response (+28\% to SSP). In 5 trials, there was a trend for the response from Longlife relative to SSP or TSP to increase over time, but in trial 3 the reverse trend occurred.

Trials 5 and 6 included RPR which was lower yielding $(\mathrm{P}<0.05)$ than SSP in year 1 . but increased in relative effectiveness over time (Figure 1). Overall, there was a trend for Longlife to be intermediate between RPR and SSP in all years.

Estimates of the substitution value $(\Psi$ for all trials averaged 0.66 .0 .75 and 0.79 in years 1.2 and 3 respectively (Table 4). This indicates that the pasture yield from Longlife at a given rate of total $\mathrm{P}$ could have been obtained with a lower rate (from $\Psi$ ) of total P as SSP or TSP.

Table 3 Average pasture production (kg DM/ha/year) from nil P, Longlife and SSP or TSP in 6 field trials (see Table-l for site details). Fertilizer data are the average of $3 \mathrm{P}$ rates estimated for equivalent rates of total $\mathrm{P}$ applied.

\begin{tabular}{|c|c|c|c|c|}
\hline Trial No. & nil $P$ & Longlife & SSP or TSP & $\operatorname{LSD}(5 \%)$ \\
\hline \multicolumn{5}{|l|}{ Yearl: } \\
\hline 1 & 9770 & 10550 & 10595 & 540 \\
\hline $2^{b}$ & 5125 & 5625 & 5800 & 410 \\
\hline 3 & 7790 & 8680 & 8830 & 420 \\
\hline 4 & 8310 & 9150 & 9540 & 420 \\
\hline 5 & 8210 & 8690 & 8920 & 430 \\
\hline 6 & 9720 & 10180 & 10440 & 390 \\
\hline Mean & 8154 & 8813 & 9021 & $122^{+*}$ \\
\hline \multicolumn{5}{|l|}{ Year 2: } \\
\hline 1 & 11420 & 12510 & 12600 & 425 \\
\hline 2 & 11660 & 13200 & 13810 & 650 \\
\hline 3 & 6720 & 7570 & 7880 & 490 \\
\hline 4 & 8690 & 9690 & 9490 & 500 \\
\hline $\mathbf{5}^{\mathbf{b}}$ & 6040 & 7340 & 7770 & 460 \\
\hline $6^{b}$ & 5600 & 6770 & 7160 & $380^{\circ}$ \\
\hline Mean & 8355 & 9513 & 9785 & $301 t$ \\
\hline \multicolumn{5}{|l|}{ Year 3: } \\
\hline 1 & 7030 & 8060 & 8035 & 210 \\
\hline 2 & 9640 & 10385 & 10435 & 410 \\
\hline 3 & 6420 & 7300 & 7760 & 600 \\
\hline $\begin{array}{l}4 \\
5\end{array}$ & $\begin{array}{l}8830 \\
6030\end{array}$ & $\begin{array}{r}10270 \\
7230\end{array}$ & $\begin{array}{r}10260 \\
7470\end{array}$ & $\begin{array}{l}500 \\
450\end{array}$ \\
\hline $6 "$ & 6330 & 7680 & 7790 & 470 \\
\hline Mean & 7380 & 8488 & 8625 & 195 \\
\hline \multicolumn{5}{|l|}{ Year 4: } \\
\hline 4 & 7650 & 9910 & 10010 & 760 \\
\hline $5^{b}$ & 4300 & 6530 & 6790 & 540 \\
\hline 6 & 6390 & 9100 & 9430 & 660 \\
\hline
\end{tabular}

For comparison between fertilisen; $t$, 'and "Indicate 10,5 and $1 \%$ level of significance.

Lessthanl year 

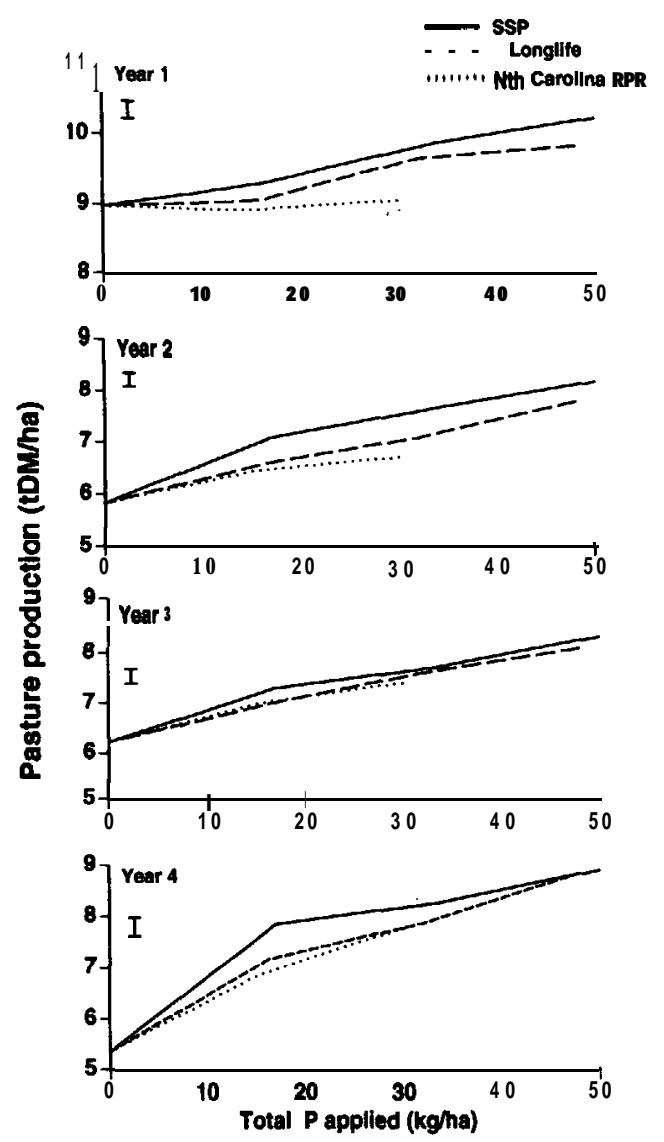

Floure 1 Effect of $P$ fertilisers on pasture production over 4 year. Dan are the average for trials 5 and 6. Bars represent SEDs.
50:50 Longlife-type fertiliser trials

There was little response to soluble $\mathrm{P}$ fertiliser over the control treatment in the first year of these trials, averaging $4 \%$ from $0.75 \mathrm{M}$ SSP. but thereafter it increased to an average of $17 \%$ in year 5 (Figure 2). Longlife was not significantly different to SSP, although it tended to be slightly lower producing in all years. There was little response to RPR in the fit 2 years but it increased over time to near that from Longlife and SSP in years 4 and 5 .

The response from Longlife averaged $75 \cdot 78 \%$ of that from SSP in the fiit 3 years and increased to $85 \%$ by the fifth year, whereas the response from RPR relative to SSP was 0 in year 1 and increased to $78 \%$ in year 5.

The $\Psi$ values (calculated relative to TSP) had relatively large errors due mainly to the use of only one rate of $\mathrm{P}$ for the various fertilisers. Nevertheless, the $\Psi$ for Longlife tended to be intermediate between that for SSP and RPR for the duration of the trials.

\section{Discussion}

The pasture response to commercially produced Longlife was less than that from SSP or TSP when averaged over all trials in the first 2 years, but the difference decreased over time. Associated measurements with RPR (Figures 1 and 2; and Sinclair 1990) also showed an initial lag in effectiveness and overall the difference

Table 4 Substitution values $(Y)$ for Longlife and other $P$ fertilisen in 11 field trials. $\Psi$ is the ratio of toxal $P$ in a standard (TSP or SSP) to toual $P$ in the fertilisers for the same pasture production. Bracketed values are standard errors.

\begin{tabular}{|c|c|c|c|c|c|c|c|}
\hline \multirow{2}{*}{$\begin{array}{l}\text { Trial } \\
\text { Number }\end{array}$} & \multicolumn{7}{|c|}{ Time (years) } \\
\hline & 1 & 2 & 3 & 4 & 5 & $6^{\bullet}$ & Total" \\
\hline
\end{tabular}

\section{Commerclal Longllte}

\begin{tabular}{|c|c|c|c|c|c|c|c|c|c|c|c|}
\hline 1 & 0.77 & $(0.28)$ & $0.88(0.11)$ & 1.00 & $(0.17)$ & & & & & & \\
\hline 2 & 0.62 & $(0.16)$ & $0.44(0.08)$ & 0.73 & $(0.14)$ & & & & & & \\
\hline 3 & 0.73 & $(0.17)$ & $0.62(0.17)$ & 0.34 & $(0.14)$ & & & & & & \\
\hline $\begin{array}{l}4 \\
5^{c}\end{array}$ & 0.50 & $(0.23)$ & $\begin{array}{l}1.33(0.52) \\
0.59(0.08)\end{array}$ & 0.98 & $(0.18)$ & $\begin{array}{l}0.95 \\
0.85\end{array}$ & $\begin{array}{l}(0.15) \\
(0.10)\end{array}$ & & & & \\
\hline 8 & 0.67 & $(0.04)$ & $0.88(0.12)$ & 0.89 & $(0.13)$ & & & & & & \\
\hline Mean & \multicolumn{2}{|c|}{0.68} & 0.75 & 0.79 & & & & & & & \\
\hline \multicolumn{12}{|c|}{$\begin{array}{l}\text { 50:50 Longllite-type fertlliser } \\
7.11\end{array}$} \\
\hline SSPd & 0.89 & $(0.88)$ & $0.92(0.54)$ & 1.03 & $(0.47)$ & 0.80 & $(0.33)$ & $0.91 \quad(0.38)$ & $1.16(0.34)$ & 0.91 & $(0.32)$ \\
\hline Longlifet & 0.86 & $(0.56)$ & $0.62(0.42)$ & 0.69 & $(0.37)$ & 0.63 & $(0.29)$ & $0.71 \quad(0.32)$ & $0.93(0.29)$ & 0.87 & $(0.27)$ \\
\hline APR & -0.27 & (0.49) & $0.25(0.31)$ & 0.43 & $(0.31)$ & 0.70 & $(0.31)$ & $0.67(0.31)$ & $0.75(0.25)$ & 0.45 & $(0.22)$ \\
\hline
\end{tabular}

\section{Excluding trial 8}

Based on total production for years $1-5$

Missing values where unsuitable response curves occurred

All values relative to TSP 


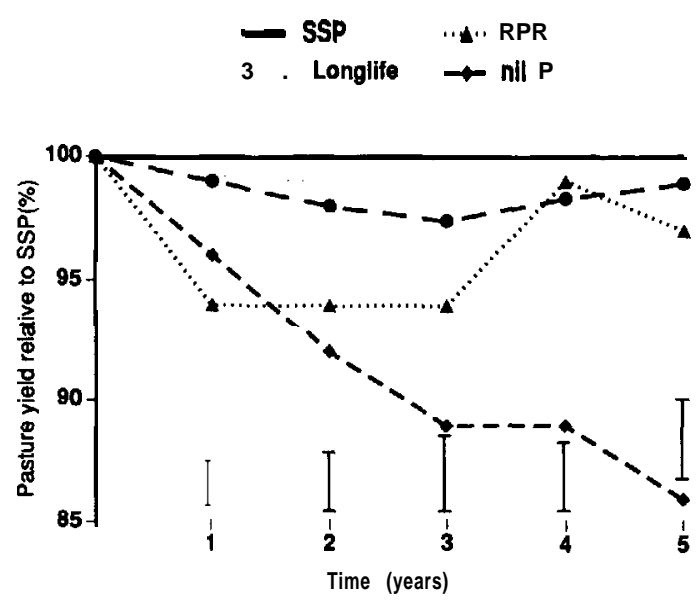

Figure 2 Effect of $P$ fertilisers on annual pasture production expressed as to relative to SSP. Bars represent SEDs.

between RPR and SSP or TSP tended to be greater than that for Longlife. Thus, the results are consistent with Longlife performing agronomically as expected from a non-interacting mixture of its components (eg. 70\% SSP and $30 \%$ RPR in most commercial Longlife).

Bolan et al. (1987) measured the chemical reactions that occurred in the preparation of Longlife in a laboratory and found that when RPR was added to SSP ex-den. residual free acid preferentially consumed the RPR and this resulted in reduced acidulation of the unreactive PR used for the SSP. However, they noted that in acommercial works the den temperature is higher than in their laboratory study and that this would favour greater acidulation of the unreactive PR. A significant increase in unreactive PR (from which little $P$ becomes plantavailable) in Longlife compared to SSP would mean reduced agronomic effectiveness in the long term, but this was not evident in the field trials. In practice. there is less likelihood of this being an issue because SSP is being manufactured using an increasing component of PRs of higher reactivity than in the past,

Longlife may not be an appropriate phosphatic fertiliser for all situations. The field trials indicated that it functioned as a simple mixture of its components and this suggests that it is inappropriate in field conditions unsuitable for RPR. It is currently recommended that RPRs should not be used on soils with a $\mathrm{pH}$ above 6.0 and/or where rainfall is less than $800 \mathrm{~mm}$ (Sinclair 1990). These conditions may also be appropriate for Longlife, and in such conditions soluble $P$ fertiliser (eg. SSP or TSP) should be used.

Results from these trials should not be extrapolated to partially acidulated PRs (PAPRs) because PAPRs are manufactured differently from Longlife. Indeed, in the
MAF National Series of $P$ trials (Smith et al. 1991) PAPR made using phosphoric acid was as effective as SSP or TSP in all conditions. In the 5 trials from the National Series described in this paper, the $\boldsymbol{\Psi}$ for PAPR relative to TSPover 5 years was 1.09 whereasitwas 0.67 for the 50:50 Longlife. However, in some situations (eg. low level of acidulation, different acid, or hard granules) PAPRs have also been initially less effective than SSP or TSP (Rajan et al. 1993).

\section{Conclusions}

1. Longlife phosphatic fertiliser appears to function as expected from a non-interacting mixture of its components (commonly 70\% SSP and $30 \%$ RPR).

2. When Longlife is first used, there may be a small lag in pasture response compared to that from SSP.

3. Soluble $P$ fertiliser (eg. SSP. TSP) is more appropriate than Longlife when conditions are unsuitable for RPR (soil $\mathrm{pH}$ exceeding 6.0 and/ or rainfall less than $800 \mathrm{~mm}$ ).

\section{ACKNOWLEDGEMENTS}

The conduct of trials 7 . 11 by AgResearch scientific staff throughout New Zealand was greatly appreciated. We also thank M. Hawke.T. Gee,M.Boyes and K. Jones for technical assistance with trials 1 to 6 and C. Smith and J. Waller for statistical analyses. BOP Fertiliser Ltd provided financial assistance for trials 1 and 2.

\section{REFERENCES}

Bolan. N.S.; Hedley. M.J.; Syers, J.K.; Tillman, R.W. 1987. Single and superphosphate-reactive phosphate rock mixtures. 1. Factors affecting chemical composition. Fertilizer research 13: 223239.

Johnstone, P.D.; Sinclair, A.G. 1991. Replication requirements in field experiments for comparing phosphatic fertilisers. Fertilizer research 29: 329-333.

Mackay, A.D.; Wewela, G.S. 1990. Evaluation of partially acidulated phosphate fertilisers and reactive phosphate rock for hill pastures. Fertilizer Research 21: 149-156.

Rajan. S.S.S.; Ledgard, S.F.; Thorrold, B.S. 1993. Field evaluation of partially acidulated phosphate rocks as fertilisers for permanent pastures. Proceedings XVII International Grassland Congress: (ii press). 
Sinclair, A.G.; 1990. Long term effectiveness of reactive phosphate rock as a phosphate fertiliser for New Zealand pastures. Proceedings NZ Grassland Association 51: 101-104.

Smith, L.C.; Johnstone. P.D.; Sinclair, A.G.; Shannon, P.W.; O'Connor, M.B.; Percival, N.; Roberts, A.H.; Smith, R.G.; Mansell, G.; Morton, J.D.; Nguyen, L.; Dyson, C.B.; Risk, W.H. 1990. Final report on the MAF "National Series" forms of phosphate fertiliser trials. 1. Description of trials and annual herbage dry matter production. MAF. Wellington. 